\title{
PELATIHAN PERCAKAPAN BAHASA JEPANG PRAKTIS BAGI GENERASI MUDA DI DESA PASSO KECAMATAN KAKAS
}

\author{
Sandra Rakian \\ Prodi Pendidikan Bahasa Jepang, Fakultas Bahasa dan Seni, Universitas Negeri Manado (UNIMA) \\ sandrarakian@gmail.com
}

\begin{abstract}
Abstrak
Tujuan kegiatan yang ingin dicapai melalui kegiatan pengabdian ini adalah untuk meningkatkan pengetahuan Generasi muda yang ada didesa Passo Kecamatan Kakas yang tergabung dalam wadah Pakasaan Passo Indonesia (PPI) tentang bahasa Jepang dalam hal ini tentang guiding yang berisi percakapan praktis yang baik dan benar. Pengetahuan yang diberikan berkenaan dengan menunjang pariwisata yang ada diSulawesi Utara yang artinya dibutuhkan keterampilan berbicara yang baik sebagai modal dalam berkomunikasi dengan wisatawan. Metode yang dilakukan adalah metode ceramah dengan melakukan kegiatan pelatihan secara langsung kepada Generasi muda yang ada didesa Passo Kecamatan Kakas yang tergabung dalam wadah PPI yaitupelatihan yang dilakukan berupa ceramah, tanya jawab dan praktek. Kegiatan pengabdian pada masyarakat dalam bentuk pelatihan bahasa Jepang praktis pada Generasi muda yang ada didesa Passo Kecamatan Kakas telah berhasil dilaksanakan dengan baik. Pelaksanaan pelatihan ini telah mencapai tujuan yang dilaksanakan karena semua peserta dapat menguasai dan menggunakan bahasa Jepang sederhana.
\end{abstract}

Kata Kunci: Bahasa Jepang Praktis, generasi muda, Desa Passo.

\section{PENDAHULUAN}

\section{Analisis Situasi}

Generasi Muda sebagai pewaris, penerus cita-cita perjuangan bangsa dan sebagai sumber insani bagi pembangunan nasional, ibarat mata rantai yang tergerai panjang, posisi generasi muda dalam masyarakat menempati mata rantai yang paling sentral dalam artian bahwa, pemuda berperan sebagai pelestari nilai budaya, kejuangan, pelopor dan perintis pembaruan melalui karsa, karya dan dedikasI. Selain itu pemuda juga mempunyai peran dalam menggerakkan pembangunan sekaligus menjadi pelaku aktif dalam proses pembangunan nasional serta berperan dalam memperkokoh Persatuan dan Kesatuan Bangsa

Paso adalah desa di kecamatan $\underline{\text { Kakas, Minahasa, Sulawesi Utara, Indonesia. }}$
Ibukota kecamatan Kakas terletak dibagian Tenggara Kabupaten Minahasa, batasbatas wilayah ;Bagian Utara: Kecamatan Eris, Lembean Timur, Bagian Timur: Laut Maluku, Bagian selatan: Kecamatan Langowan Timur dan Bagian Barat: Kecamatan Tompaso. Luas wilayahnya $110.65 \mathrm{Km}^{2}$. Desa yang termasuk pada kecamatan kakas: Wasian, Kalawiran, Panasen, Totolan, Paso, Tountimomor, Tounelet, Talikuran, PahaletenSendangan , Paslaten, Kaweng, Toulimambet, Simbel, Wailang, Bukit Tinggi, Kayuwatu Wineru, Rinondor, Touliang. Penggunaan lahan umumnya digunakan sebagai lahan pertanian dengan luas 9.500 hektar yang ditanami (cengkih, kelapa, jagung, cengkih, pala, vanili, kakao), selain itu digunakan sebagai lahan untuk kawasan hutan penyangga dan pemukiman. Jenis tanah 
adalah Latosol dengan pH 4,5 -8 terletak pada ketinggian 0-500 dari permukaan laut. Umumnya wilayah kecamatan Kakas mempunyai topografi wilayah Datar sampai dengan curamJumlah Penduduk : 22.172 (tahun 2003).

Pemuda dalam tiap masa selalu menjadi tulang punggung sebuah perubahan. Apakah itu perubahan menuju lebih baik atau sebaliknya. Pemuda dalam definisi sosial adalah generasi antara umur 20 - 40 tahun ( atau 18- 35 tahun dalam referensi lain). Dalam kajian ilmu sosial, puncak kematangan peran publik seorang manusia ialah antara umur 40 -60 tahun. Dari perbandingan di atas, kita dapat menyimpulkan, bahwa pemuda adalah penerus generasi sebelumnya untuk masa yang akan datang.Pembangunan pendidikan dan pengembangan generasi muda merupakan bagian integral dari upaya pengembangan sumber daya manusia di berbagai bidang.

Rahasia berikutnya adalah keunggulan mengorganisasi kekuatan. Ada setidaknya lima faktor prinsip yang dipegang pemuda, dalam mengorganisasi kekuatan mereka, yaitu :

1. Kekuatan asas perjuangan

2. Kekuatan konsep dan metode perjuangan

3. Kekuatan persatuan

4. Kekuatan sikap dan posisi perjuangan

5. Kekuatan aksi dan opini : memiliki isu sentral, konsistensi misi, imun dalam perjuangan, kesinambungan aksi dan opini.

Disaat kondisi bangsa seperti saat ini peranan pemuda atau generasi muda sebagai pilar, penggerak dan pengawal jalannya reformasi dan pembangunan sangat diharapkan. Dengan organisasi dan jaringannya yang luas, pemuda dan generasi muda dapat memainkan peran yang lebih besar untuk mengawal jalannya reformasi dan pembangunan. Permasalahan yang dihadapi saat ini justru banyak generasi muda atau pemuda yang mengalami disorientasi, dislokasi dan terlibat pada kepentingan politik praktis. Seharusnya melalui generasi muda atau pemuda terlahir inspirasi untuk mengatasi berbagai kondisi dan permasalahan yang yang ada. Pemuda atau generasi muda yang mendominasi populasi penduduk Indonesia saat ini mesti mengambil peran sentral dalam berbagai bidang untuk kemajuanUntuk itu dibutuhkan peran aktif pemuda dan remaja dalam menunjang sektor pariwisata.

\section{Target dan Luaran}

Tujuan kegiatan yang ingin dicapai melalui kegiatan pengabdian ini adalah untuk meningkatkan pengetahuan Generasi muda yang ada didesa Passo Kecamatan Kakas yang tergabung dalam wadah Pakasaan Passo Indonesia (PPI) tentang bahasa Jepang dalam hal ini tentang guiding yang berisi percakapan praktis yang baik dan benar. Pengetahuan yang diberikan berkenaan dengan menunjang pariwisata 
yang ada diSulawesi Utara yang artinya dibutuhkan keterampilan berbicara yang baik sebagai modal dalam berkomunikasi dengan wisatawan.

Dengan adanya kegiatan pelatihan ini diharapkan dapat memberikan pengetahuan bahasa Jepang kepada Generasi muda yang ada didesa Passo Kecamatan Kakas dan peningkatan kualitas sumber daya manusia melalui kegiatankegiatan kemasyarakatan dalam wadah Pakasaan Passo Indonesia (PPI)

\section{METODE PELAKSANAAN}

Bahasa merupakan alat komunikasi yang paling efektif untuk menyampaikan gagasan, pikiran. Setiap hari manusia selalu berkomunikasi dengan sesamanya. Mitra komunikasi bermacam-macam, bisa dengan seseorang yang latar belakang sosialnya sama ataupun yang berlainan. Bahasa adalah sistem bunyi ujaran yang bersifat manasuka yang dapat digunakan dalam komunikasi interpersonal oleh sekumpulan orang. Sebagai alat komunikasi bahasa disampaikan melalui dua cara yaitu bahasa lisan dan bahasa tulisan. Setiap bahasa memiliki pedoman penggunaan atau tata aturan tertentu yang sebaiknya dipelajari agar dapat digunakan dengan baik dan benar sehingga dapat menimbulkan respon (feed back) yang baik antara pengguna bahasa tersebut.

\footnotetext{
Dengan masuknya perdagangan bebas, maka persaingan perdagangan dengan negara lain menjadi begitu ketat.
}

Oleh karena itu bahasa menjadi salah satu aspek yang sangat penting, karena bahasa merupakan salah satu alat komunikasi yang sering digunakan. Bahasa yang sering di gunakan antara lain adalah bahasa Jepang. Maka agar tidak ketinggalan dengan perkembangan dunia yang semakin modern ini,kita semua yang ingin maju, harus mempersiapkanya dalam persaingan di era perdagangan bebas ini, yaitu dengan belajar bahasa jepang. Perkembangan zaman banyak menimbulkan perubahan dan kemajuan dalam berbagai segi kehidupan dalam masyarakat. Antara lain ilmu pengetahuan dalam aspek sosial, politik, ekonomi,industri dan sebagainya. Perkembangan berbagai lapangan kerja, merupakan salah satu masalah yang sering terjadi sekaligus peluang sebagai akibat perubahan dan kemajuan. Tuntutan kehidupan di zaman modern ini lebih tinggi dan lebih kompleks hal ini menyebabkan munculnya persyaratan tertentu bagi setiap orang yang ingin memasuki dunia pekerjaan. Salah satu contohnya;harus bisa menguasai bahasa jepang. Agar sekolah dapat menyesuaikan pendidikannya dengan berbagai kehidupan, maka isi kurikulum dan proses belajar mengajar sekolah harus memperhitungkan berbagai kenyataan yang terjadi di lingkungan sosial, mengingat pentingnya bahasa Jepang maka seharusnya di SMP/SMA/ SMK, merupakan salah satu mata pelajaran yang harus diikuti oleh semua siswa.

Sebagai Generasi muda yang ada didesa Passo Kecamatan Kakas, tentunya 
memiliki fungsi dan peran penting dalam upaya pembinaan dan pengembangan bahasa Jepang.Upaya penggunaan bahasa Jepang dalam hal ini percakapan sehari-hari yang baik dan benar oleh pemuda dan remaja belum dilakukan secara optimal dan peranannya belum berjalan sebagaimana
semestinya.Hal ini disebabkan karena kurangnya bahkan mungkin tidak memiliki pengetahuan tentang bahasa Jepang dasar. Faktor lain disebabkan karena beragamnya latar belakang pendidikan dari pemuda dan remaja yang tergabung dalam wadah karang taruna.

Tabel 1. Kondisi yang ada dan kondisi yang diharapkan.

\begin{tabular}{|c|c|c|}
\hline Kondisi yang ada & Bimbingan/Pelatihan & Kondisi yang diharapkan \\
\hline $\begin{array}{l}\text { 1. Pengetahuan bahasa } \\
\text { Jepang yang minim pada } \\
\text { pemuda dan remaja } \\
\text { 2. Tidak terciptanya } \\
\text { komunikasi dengan } \\
\text { wisatawan Jepang }\end{array}$ & $\begin{array}{l}\text { Faktor-faktor penunjang: } \\
\text { 1. Adanya tenaga pengajar } \\
\text { yang siap memberikan } \\
\text { pelatihan } \\
\text { 2. Adanya keinginan dari } \\
\text { pemuda dan remaja untuk } \\
\text { belajar bahasa Jepang } \\
\text { Faktor-faktor penghambat: } \\
\text { 1. Keterbatasan waktu; } \\
\text { peserta hanya bisa pada } \\
\text { sore hari }\end{array}$ & $\begin{array}{l}\text { 1. Para pemuda dan Remaja } \\
\text { dapat mengetahui } \\
\text { kalimat-kalimat } \\
\text { percakapan bahasa Jepang } \\
\text { sederhana dan dapat } \\
\text { menggunakannya. } \\
\text { 2. Tercipta komunikasi yang } \\
\text { baik antara pemuda, } \\
\text { remaja dan wisatawan } \\
\text { Jepang }\end{array}$ \\
\hline
\end{tabular}

Untuk menjawab masalah diatas cara metode yang dilakukan adalah metode ceramah dengan melakukan kegiatan pelatihan secara langsung kepada Generasi muda yang ada didesa Passo Kecamatan Kakas yang tergabung dalam wadah PPI yaitupelatihan yang dilakukan berupa ceramah, tanya jawab dan praktek. Pemecahan masalah ini dimaksudkan untuk mengubah kondisi yang ada (dasa sain) yaitu para Generasi muda yang ada didesa Passo Kecamatan Kakas tidak dapat berkomunikasi dengan wisatawan mancanegara (Jepang). Kondisi ini akan dibawa pada suatu kondisi yang diharapkan (das solen) yaitu Generasi muda yang ada didesa Passo Kecamatan Kakas dapat menguasai bahasa Jepang sesederhana 60 mungkin sehingga tercipta komunikasi yang baik dengan wisatawan Jepang dalam bentuk komunikasi praktis.

\section{HASIL DAN PEMBAHASAN}

Kegiatan pelatihan perancangan Media pembelajaran melibatkan seluruh Generasi muda yang ada didesa Passo Kecamatan Kakas. Kegiatan ini telah dilaksanakan bertempat di rumah keluarga Sumayku-Rakian dan diikuti oleh Generasi muda yang ada didesa Passo Kecamatan Kakas. Metode yang digunakan dalam kegiatan penyuluhan yang dilaksanakan relevan dengan pokok permasalahan yang disesuaikan dengan tujuan yang ingin dicapai adalah yaitu metode presentasi, tanya jawab, demonstrasi dan pemberian tugas. 
Pelaksanan pelatihan bahasa Jepang bagi pada Generasi muda yang ada didesa Passo Kecamatan Kakas hasilnya sebagai berikut:

1. Adanya respon positif baik dengan dari pemerintah maupun dari masyarakat. Ini ditandai dengan turut hadirnya unsur pemerintah dan LPM desa Passo kecamatan Kakas

2. Animo peserta baik pemuda dan remaja yang sangat antusias dan penuh kesungguhan dalam mengikuti pelatihan ini.

3. Peserta sudah mengetahuidan dapat menggunakan ungkapan-ungkapan persalaman, bentuk-bentuk kalimat percakapan praktis dalam bahasa Jepang.

Dari hasil evaluasi serta respon positif sebagaimana yang diungkapkan diatas maka dapatlah dikemukakkan berbagai hal sebagai berikut:

1. Pelatihan bahasa kepada pemuda dan Remaja merupakan suatu kegiatan yang cukup baik dan efektif karena dapat membekali peserta dengan pengetahuan dan kemampuan untuk berkomunikasi.

2. Meningkatkan rasa percaya diri terutama bagi pemuda dan remaja terutama bagi mereka yang tingkat pendidikannya rendah.

3. Dengan adanya kemampuan komunikasi bahasa Jepang yang sederhana akan tercipta komunikasi yang baik dengan wisatawan Jepang. Keadaan ini juga turut membantu menyukseskan Manado sebagai kota pariwisata Dunia (MKPD) tahun 2020.

\section{KESIMPULAN DAN SARAN}

\section{Kesimpulan}

1. Kegiatan pengabdian pada masyarakat dalam bentuk pelatihan bahasa Jepang praktis pada Generasi muda yang ada didesa Passo Kecamatan Kakas telah berhasil dilaksanakan dengan baik.

2. Pelaksanaan pelatihan ini telah mencapai tujuan yang dilaksanakan karena semua peserta dapat menguasai dan menggunakan bahasa Jepang sederhana.

\section{Saran}

Dengan melihat keberhasilan yang diperoleh serta animo masyarakat/peserta maka disarankan agar kegiatan pengabdian pada masyarakat dalam bentuk pelatihan berupa kusus singkat seperti ini perlu ditindak lanjuti pada lokasi yang sama maupun lokasi yang lain dengan topic/materi yang sama (Bahasa Jepang) ataupun bahasa Asing lainya. Mengapa dikatakan demikian karena wisatawan mancanegara yang nantinya akan berkunjung kemanado sangat beragam.

\section{KEPUSTAKAAN}

Sudjono, Anas. 1996. Pengantar Evaluasi Pendidikan. Jakarta: PT.Rajagrafindo Persada

Syaodih Sukmadinata, Nana. 2006. Metode Penelitian Pendidikan. Bandung: 
Jurnal ABDIMAS, Vol. 11, No. 1, April 2018

ISSN: 1979-0953 | e-ISSN: 2598-6066

Program Pascasarjana UPI \& PT. Remaja Rosdakarya

Suzuki,S dan kawase. 1979. Nihongo Shoho. Japan: The Japan Foundation

Tarigan. 1987. Teknik Pengajaran Keterampilan Berbahasa. Bandung : Angkasa
Trihendradi, Cornelius. 2005. Step by Step SPSS $13 \quad$ Analisis Data Statistik.Yogyakarta:Andi Ofset

Widodo, Edi. 2006. Multimedia dan Pembelajaran Bahasa. Bandung 